$$
\begin{array}{cccc}
\text { S sciendo } & \text { International Conference KNOWLEDGE-BASED ORGANIZATION } \\
\text { Vol. XXV } & \text { No 3 } & 2019
\end{array}
$$

\title{
THE IMPERATIVE NEED TO CREATE A RAPID AND EFFICIENT CONNECTION BETWEEN TRANSYLVANIA AND BUKOVINA DURING THE FIRST WORLD WAR - THE CONSTRUCTION OF THE PRUNDU BÂRGĂULUI - VATRA DORNEI RAILWAY LINE
}

\author{
Lia-Maria CIOANCA \\ „Babeș-Bolyai” University, Cluj-Napoca, Bistrița Extension, Romania \\ lia_cioanca@yahoo.com
}

\begin{abstract}
In the context of the World War I outbreak and given the lack of a direct railway line between Transylvania and Bukovina, the Austro-Hungarian army is forced to find a quick and operative solution to the supply of weapons, food, but also to restore the supply to the AustroHungarian empire with manganese ore, dolomite, lumber, cereals, animals and other goods provided by Bukovina. Therefore, they considered building a fast link between Transylvania and Bukovina, along a spectacular route, namely, the Prundu Bârgăului-Vatra Dornei railway line. In the successful realization of this great project an ingenious, even revolutionary solution was found for those days: the construction of a railway line with normal gauge, adapted to trains and the petrol-electric traction, according to a model that was used and successfully put into practice since 1912 in Austrian Tirol. The works were completed in a very short time, even though there were very harsh working conditions and the route was extremely difficult. Both the Austro-Hungarian army and civilians from neighbouring villages and prisoners of war contributed to this success.
\end{abstract}

\section{Keywords: war, army, need, railway line, technology}

\section{The Historical-Political Context}

1914 was the year when the frustrations and expansionary tendencies of European countries were unleashed and nearly the entire world was dragged down into a bloody conflict. The outbreak of World War I in 1914 made the lack of a rail link between Transylvania and Bukovina to stand as a major problem for the AustroHungarian army, after the Russian troops occupied a large part of Galicia in the same year and disrupted links between Bukovina and the rest of the Empire. At the end of 1914, the command of the Imperial-Royal Austrian-Hungarian Army (Kaiserlich und Königliche Armee) is forced to take into account the construction of railways needed to create additional transport and supply links for the troops blocked here; Cavalry General Karl Freiherr von Pflanzer-Baltin Maltici also decided to prepare a harsh counter-offensive and began to deploy important units on the border of Bukovina with Transylvania, forming the so-called "Armee-GruppePflanzer-Baltin" known after 8 May 1915 as the 7th Army. The very short time span and rough terrain did not allow for the use of a route that could be safe, optimal and easy operation (small slopes, broad curves), as it could have been naturally performed during peacetime, which meant the construction of some works of art (viaducts, bridges and tunnels), proper layout of embankments in cuttings 
by carrying out excavations in rocky slopes, for embankments [5]. transporting materials and making fillings

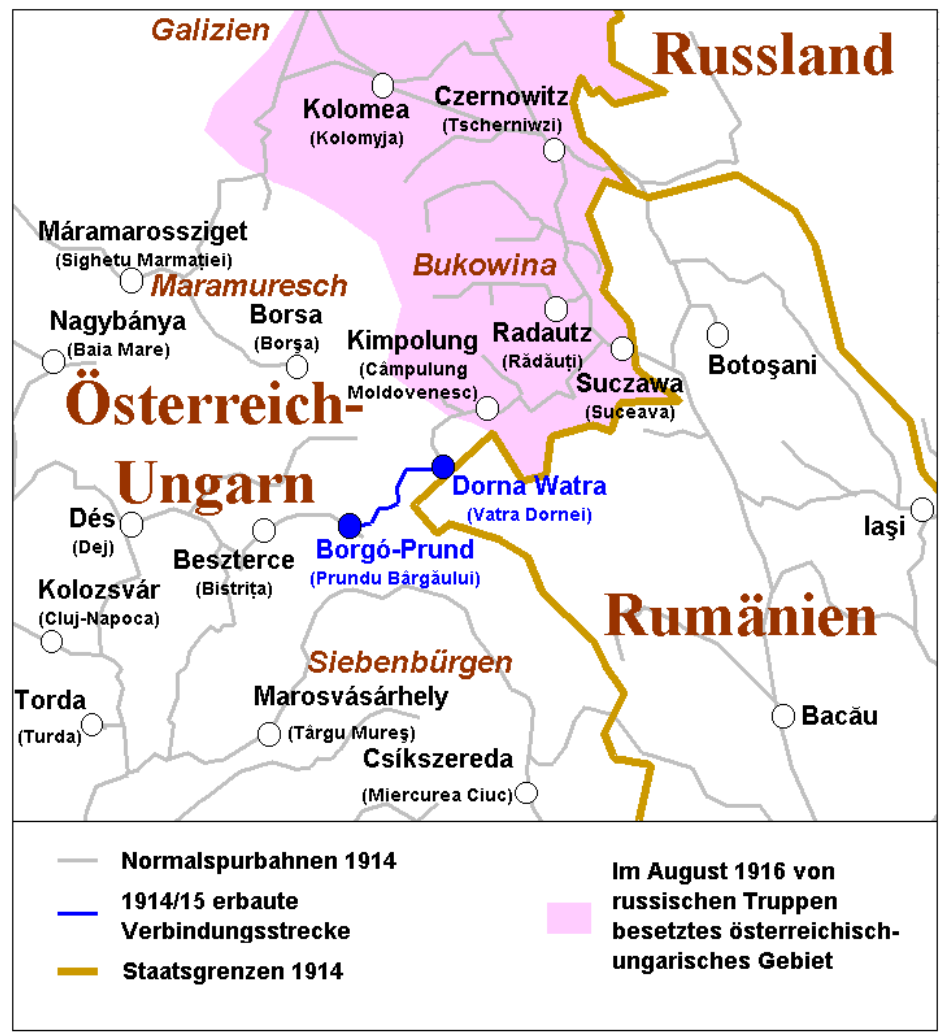

Figure 1: Route PrunduBârgăului-VatraDornei, built in 1914/1915[6]

Fortunately, however, there were specialists for the construction of railway lines necessary to solve the immediate needs of the army, as well as alternative technical solutions that could provide solutions to these problems, by using the route of roads that were already functional, following the declivity of the field, cumulated with the execution of some works of art with provisional features.

In order to reach Transylvania more easily and from here further on to the heart of the Empire, it was mandatory to use part of the railway tracks built up to that time, namely the one built from Satu Mare or Stanislau (today Ivano-Frankivsk) towards Sighetu Marmatiei and from here on the Viseu Valley to Borsa; the one who came from Dej to Bistrița to Bistrița Bârgăului or who linked the town of Beclean to the mining area in Rodna Veche [2].

\section{Therailway Construction - a Factor of Progress, Economic Development and a Component of Military Strategy}

Ever since their occurrence, railway networks have represented a factor of progress, as they played an important role in economic development, but they also represented a strength component and armed imposition through the potential they offered, being immediately included in the military strategy of developed countries as the best means of transportation and supply of troops [2].

The 19th century brought about an increase in the economic relations between Galicia, Bukovina and Transylvania and the idea of building a railway line that would allow for shorter connections to Vienna and Budapest was deemed necessary, as this alone could have provided a better alternative, a safer 
and more economical one, in order to develop business relationships those days. Due to the fact that certain financial and political interests opposed the building of a shorter direct rail link, which would cross Transylvania and then pass through Năsăud to Bucovina, a longer, bypassing route was chosen. The railway link between Vienna, Galicia and Bukovina was carried out during 1836-1866 [3].

Taking into account the growing needs of the army regarding the supply of weapons, ammunition, artillery, food and medicine, the evacuation of the wounded and fighting techniques, along with the need to supply the steel and weapon plants located behind the front with ores and raw materials, as well as other military and strategic issues, three route options were identified that were valid for the construction of military lines:

- from Tiha Bârgăului over Măgura Calului Mountain, using the road built in 1848 , to Piatra Fântânele; from here, by using a road on which carts could reach Dornişoara on a route of approximately $33.2 \mathrm{~km}$, which offered the possibility to be carried out over a relatively short time span. From Dorna Völgy (Dornişoara), it was possible for travellers to reach Vatra Dornei by using the infrastructure of forest railway lines that had already been built, the route with a length of $32 \mathrm{~km}$ being somewhat easier for exploitation;
- from Borşa through the Prislop Pass, then from Bistrița Valley to Iacobeni, by means of building a railway that was about $80 \mathrm{~km}$ long and by making use of an existing road through a difficult route with many curves of small radius and large declivities, longer execution time and more workforce;

- from Floreni to Coşna and Grădiniţa, then on the valley of Silhoase, descending to Ilva de Sus (Lunca Ilvei). This 62- km long route was meant to take start by using the Ilva Mică forest line at Lunca Ilvei and another line that was linking a timber factory in Vatra Dornei to the village of Floreni [2].

The options were thoroughly analyzed and extremely well-executed execution plans were prepared for each of them by a team of Austrian officers. It was established that all these were necessary and work would start as soon as possible, according to the evolution and the unfolding of the conflict as well as to pecuniary possibilities. In addition to these great projects, during the conflict, the secret construction of a narrow-track military railway line on the Bistrița valley, from Vatra Dornei to Broșteni, was required, whose purpose was to supply the front line with all the necessary materials.

The first work that started in force was the railway line built from Vatra Dornei to Prundu Bârgăului through Dornişoara, which began on December $1^{\text {st }} 1914$ [2]. 


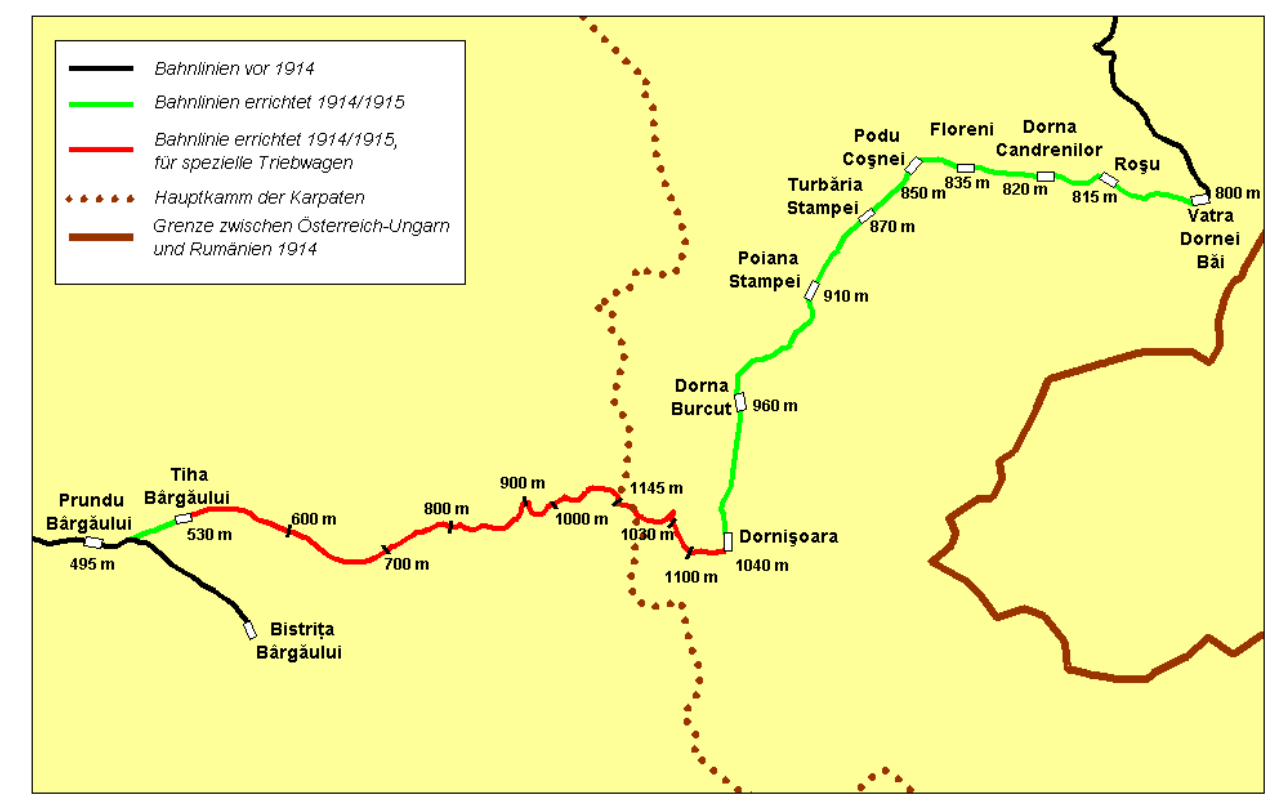

Figure 2: Track of the specified altitude railway line [6]

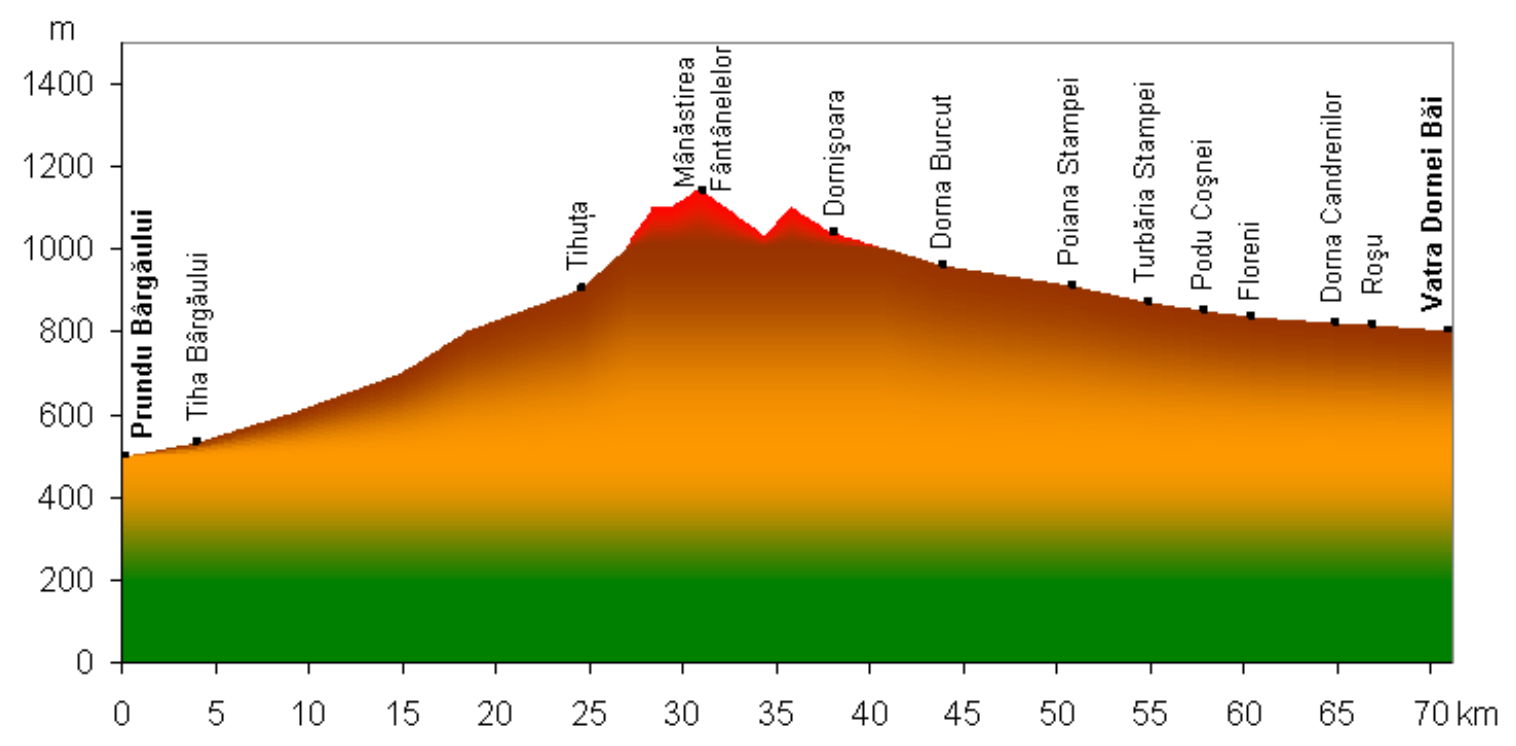

Figure 3: Rail Profile at Height[6]

Emperor Franz Joseph's visit to Vatra Dornei in December 1914 changes the situation and gives an impetus to the start of the rest of the projects on the waiting list. In addition, plans are being made to start a military campaign that releases the territory of Bukovina occupied by the Russians and restores the rather wrinkled image of the Austrian army. Shortly, that is, in early 1915, work begins at the line from Ilva
Mică through the Lunca Ilvei to the Coşna and the railway from Iacobeni to Borsa via Cârlibaba [4].

The building of these railroads was started under the spectrum of war, but only the first two were completed and were in service at the given time. The project of railway line which was planned to be built from Ilva Mica to Floreni was completed only 20 
years later, during the inter-war period, being a great achievement of the time.

A railway with special features was designed to reach Borgo-Prund from Dornişoara (Dorna Völgy) station, where one could establish a connection to the normal line of Someș Railways. The gaselectric railway line was built on metallic sleepers, being $33.2 \mathrm{~km}$ long and it closely followed the route of the road built in 1848 that passed over Măgura Calului Mountain, ascending $25.8 \mathrm{~km}$ from Borgo Tiha (Tiha Bârgăului) at an altitude of $520 \mathrm{~m}$, to Fântânele Monastery, situated at $1.145 \mathrm{~m}$; from this point it dropped $7.4 \mathrm{~km}$ to Dornişoara (DornaVölgy), a station located at an altitude of $1,032 \mathrm{~m}$, following the route of an older road, rarely used until then. The route was particularly difficult, having 230 curves with rays between 200 and $20 \mathrm{~m}$ and gradients up to $70 / 80 \mathrm{~mm} /$ $\mathrm{m}$, a maximum ramp of $87 \mathrm{~mm} / \mathrm{m}$, being situated on a $30 \mathrm{~m}$ radius between Măgura station The Horse and the Fântânele Monastery [2].

36 officers, about 300 civilians and more than 5,500 prisoners of war worked on the construction of this railway line, the latter being used for the heaviest type of work (preparation of broken stone, earthworks, digging and transport, building and construction works of art). The fact that people worked in very difficult conditions and the work was completed in a very short time span - on August $15^{\text {th }} 1915$ the line being in service - shows the greatness of this achievement, which equally belongs to all the camps involved in the construction of the line: the Austro-Hungarian army, civilians from neighbouring villages and Russian, Italian, and other prisoners of war. In order to overcome the problems caused by the very difficult route and the pressure of time, an ingenious, even revolutionary solution was found: the construction of a standard gauge track, adapted to trains and petrol-electric traction, according to a model used and successfully tested in 1912 in the Austrian Tyrol. The petrol-electric train - or more specifically the "Landwehrtrain" - was an idea of the Austrian general Ottokar Landwehr von Pragenau, who, in 1908, laid the foundations for the construction of a multi-traction vehicle extended to its trailers, which was able to travel both on ordinary roads and on railways. The Landwehr-train could travel both on the road and on the railroad by replacing road rims with ones of special construction adapted to rail traffic due to the fact that the distance between the wheels of an axle was equal to the normal track gauge $(1,435 \mathrm{~mm})$ after fitting these rims [2].

Gas-electric train sets circulated on the high slope from Tiha Bârgăului to Dornişoara, firstly those of type 1-A / manufactured between 1912-1914, then those that were type 2-B / 1916, consisting of an electric vehicle -generator as an " engine" and 4-5 trailers that were supplied with electricity produced by the engine. This was the only gas-electric traction line that existed in our country and it initially served for the transportation of food and ammunition to the armies occupying the heights near Vatra Dornei and Cârlibaba, and guarding the passage to Transylvania or it was also used for the evacuation of the wounded, but many wagons with cereals and other foods were transported by this means in early 1916 [1].

The line was opened without traffic safety installations, and trains were moving based on a graphic display. Each train was equipped with a portable telephone that connected to the airline was passing through the halts and with this device, the conductor received indications regarding the further train movement and the crossings with other trains, from the operator at the Dornişoara station or the one at Prundu Bârgăului. This simple system was used throughout the entire existence of the line and no railway event related to it was recorded [7]. 


\section{Current State of the Railways}

Today, travelling along the route of the former railway line, one may still notice traces and silent witnesses of those times. The wild and mysterious landscape is of remarkable beauty. The Prundu Bârgăului section of Dornişoara does not exist anymore, and the one with a single line and not electrified from Dornişoara to Floreni is mainly used for freight transport (especially wood); in 2010, there were two trains a day running one way. The section from Floreni to Vatra Dornei is single-lined and electrified and it is part of route 502 from Suceava to Ilva Mică and thus an important link between Transylvania and Bucovina. There are about 4-6 passenger and accelerated trains running on this track every day [1].

\section{References}

[1] Abutnăriței, I., O cale ferată uitată - linia "benzino-electrică” Dornișoara - Tiha Bîrgăului, în Monitorul de Dorna, 26 octombrie 2005.

[2] Brașcanu, P. (2012). Drum de fier prin praf de pușcă, Editura Stef, Iași.

[3] Brașcanu, P. (2014). Tunuri la Porțile Bucovinei 1914-1918, Cronică ilustrată, Editura Stef, Iași.

[4] Mureșan, A. (2002). Epopeea Feroviară Românească, Universitatea Petru Maior, Târgu Mureș.

[5] Turnock, D., Railway Network Development in Inter-war Romania: Economic and Strategic Motives (Dezvoltarea rețelei de căi ferate în România interbelică: Motive economice și strategice), Geographica Pannonica, 2003, Ausgabe 8, pp. 16-24.

[6] https://ro.wikipedia.org

[7] https://adevarul.ro 